\title{
Older Women's Fears of Violence: The Need for Interventions That Enable Active Ageing
}

\author{
Karen Barnett, PhD \\ Laurie Buys, $\mathrm{PhD}$ \\ Jan Lovie-Kitchin, PhD \\ Gillian Boulton-Lewis, PhD \\ Dianne Smith, PhD \\ Maree Heffernan, BBus, BA
}

Karen Barnett, BSSc, PhD (E-mail: k.barnett@qut.edu.au), is Research Fellow; Laurie Buys, BA, MS, Grad Cert, PhD (E-mail: 1.buys@qut.edu.au), is Associate Professor, Director; and Gillian Boulton-Lewis, BA, PhD, Med, FACE, TC (E-mail: g.boulton-lewis@qut.edu.au), is Professor Emeritus, Adjunct Professor; all are affiliated with the Centre for Social Change Research, Queensland University of Technology, Brisbane, Queensland, Australia.

Jan Lovie-Kitchin, MSc, LOSc Melb, GDRehab Lat, PhD, FAAO, is Associate Professor, Assistant Dean, Research and Director, Centre for Health Research, Faculty of Health, Queensland University of Technology, Kelvin Grove, Queensland, Australia (E-mail: j.lovie-kitchin@qut.edu.au).

Dianne Smith, BSc, BArch, GradDipIntDes, GradDipEd, PhD, is Senior Lecturer, School of Design, Faculty of Built Environment and Engineering, Queensland University of Technology, Brisbane, Queensland, Australia (E-mail: d.smith@qut. edu.au).

Maree Heffernan, BBus, BA, is affiliated with the Centre for Social Change Research, Queensland University of Technology, Brisbane, Queensland, Australia (E-mail: m.heffernan@qut.edu.au).

The authors acknowledge the assistance of statistician L. Nikki David in the analysis of data that supports this paper.

This paper is presented on behalf of the Triple A (Australian Active Ageing) Project which is being conducted by a group across five Faculties at QUT and includes L. Buys, J. Lovie-Kitchin, G. M. Boulton-Lewis, M. Courtney, H. Edwards, D. Anderson, R. Nayak, and M. T. Zlobicki. All of the group were involved in developing the survey.

Journal of Women \& Aging, Vol. 19(3/4) 2007

Available online at http://jwa.haworthpress.com

(C) 2007 by The Haworth Press, Inc. All rights reserved. doi:10.1300/J074v19n03_12 


\begin{abstract}
Women's fear of violence can impact negatively on their active participation in life. An ageing survey conducted with 2,620 Australian respondents aged 50 to 90 years examined aspects of work, learning, social, spiritual and emotional status, health, vision, home, life events, demographics, and asked an open-ended question about what being actively engaged in life meant. Ordinal regression was carried out on two dependent variables: wanting and needing to learn to discourage violence. Analyses found that as women's age increased, those on lower incomes were more likely than others to say they needed to learn how to discourage violence against them. This paper investigates the variables associated with the findings-transport, finances, news media, home safety, and reduced social interactions. Results highlight the importance of understanding women's fear in the context of personal and social issues, and the need to provide learning opportunities to improve safety and social engagement. doi:10.1300/J074v19n03_12 [Article copies available for a fee from The Haworth Document Delivery Service: 1-800-HAWORTH. E-mail address: <docdelivery@haworthpress.com> Website: <http://www. HaworthPress.com> () 2007 by The Haworth Press, Inc. All rights reserved.]
\end{abstract}

KEYWORDS. Older women, fear of violence, perception of risk, active ageing, home and environment

\title{
INTRODUCTION
}

Research suggest that older women have "disproportionate anxiety" about crime (James, Graycar and Mayhew, 2003, p. 45), and official crime statistics show they are less likely to be victims than other age groups. While James (1993) argues that older women's fear is "real and pervasive" others specify that for older people it is "time and place specific" (Blythe, Wright and Monk, 2004, p. 403). Unfortunately, little is known about the experiences of crime and violence for Australians over 65 years because of the small number of "official" victims, and the disaggregated nature of data (James, 2003). Low levels of victimization may also be explained by the reluctance of older people to place themselves at risk (Wiles and Simmons, 2003; Blythe et al., 2004). In Beck's (1992) risk society thesis and his subsequent works (Beck, 1995a,b) he "maintained that contemporary western society is embedded in a culture of risk which has profound impacts on the nature of everyday life" (Mythen, 2004, p. 12). A heightened sense of danger means decisions 
are made on the basis of possible risks, and dis-empowers people from participating freely in social activities (James, 1993).

Schroder-Butterfill and Marianti (2006) draw on Chambers's definition of vulnerability to highlight that "a person's risk of suffering harmher vulnerability-is the incremental outcome of a set of distinct but related risks, namely the risk of being exposed to a threat, the risk of a threat materializing, and the risk of lacking the defences to deal with a threat." This definition highlights the insidious nature of fear of violence underpinned by consideration of risks. Since current government policy prioritises ageing in place in familiar homes and neighborhoods (Olsberg, 2004, pp. 21, 22), it is essential to develop "an improved understanding of the scale and nature of crime and safety problems confronting older Australians" (James, 2003) to facilitate their safety and quality of life.

\section{AIM}

The purpose of this paper is to investigate older women's perceptions of fear and their expressed need to learn to protect themselves against violence. Findings are based on data from a large study of active ageing in the Australian context.

\section{Background to the Study}

The Triple A (Australian Active Ageing) Study, led by a team of multidisciplinary researchers, was conducted to respond to the WHO Active Ageing Policy (2005) prioritising inclusion and social justice for all. The Triple A Study investigated multiple issues related to quality of life for older adults. Although not investigating crime and violence specifically, the survey asked questions about a range of life domains and found surprising results in the section about learning needs (Purdie and Boulton-Lewis, 2003).

\section{METHOD}

\section{Survey}

A 178-item survey (later reduced to 165 variables because of some discrepancies) covered domains of paid and voluntary work (14), learning (33), social (11), spiritual (9), emotional (24), health, vision and home (50), life events (9), and demographics (14). The learning, 
social, spiritual emotional, health, vision and home, and life events items were developed from existing surveys with permission. Other sections were designed by the research team, with one open question asking respondents to describe what active ageing meant to them. Of interest to this study is the 33-question learning scale covering interest in learning new things ( 8 items), the kinds of things they needed to learn ( 7 items), what they wanted to learn ( 7 items) and what kept them from learning (11 items). This measure was modified from the Purdie and Boulton-Lewis measure, Learning Needs of Older Adults (Purdie and Boulton-Lewis, 2003).

\section{Sample}

A random sample of 6,000 people was selected from the membership database of a national senior's organisation, in the target age range $50-75+$ years. A total of 2,655 surveys were returned and after exclusion of incomplete or unacceptable returns, 2,620 were analysed. There were more female (57\%) than male respondents; the largest percentages were in the age groupings of 50-65 years (68\%) and 65-74 years (21\%), and the majority were from Eastern states of Australia. Average incomes were $>\$ 50,000(33 \%),>\$ 30,000(26 \%),>\$ 20,000(18 \%),>\$ 10,000$ $(14 \%)$ and $<\$ 10,000(5 \%)$. The majority were married $(65 \%)$, resided in their own homes $(88 \%)$, lived in metropolitan areas $(69 \%)$, were Australian born (76\%), and had tertiary qualifications (31\%), Grade 10 $(21 \%)$ or further education $(18 \%)$.

\section{Data Analysis}

Statistical analyses were conducted using two of the items from the "learning" section as dependent variables: "Do you want to learn to discourage violence against yourself?" "Do you need to learn to discourage violence against yourself?" Ordinal regression modelling with complementary log-log link function was conducted to investigate which aspects of life, such as learning, social, health, vision, home environment and demographic characteristics, predicted the likelihood of needing and wanting to learn to discourage violence. This type of modelling was used since the dependent variables, "needing" and "wanting" to learn to discourage violence, have ordered categories $(1=$ Strongly disagree to $6=$ Strongly agree) with responses favouring higher or positive values. Open comments from the question about what 
active ageing meant were entered into N-Vivo, a software application for analysis of non-numerical data, and searched for terms that could provide supplementary information for the results.

\section{RESULTS}

Results for the ordinal regression model for the first dependent variable, "the need to learn to discourage violence," are presented in Table 1. Many of the items in the questionnaire were initially included in the modelling, with only the items that emerged as the predictors included in analyses below. Respondents who were most likely to say that they needed to learn to discourage violence against them $\left[\chi^{2}(8, n=2411)=\right.$ $1262.31, p<.001]$ were

- interested in news or current event programs on radio or television;

- needed to learn to find people to trust to manage their money;

- more likely women; and

- in lower combined income brackets.

TABLE 1. Ordinal Regression Analysis with Needing to Learn to Discourage Violence as the Dependent Variable

\begin{tabular}{|c|c|c|}
\hline \multirow[t]{2}{*}{ Questions } & \multicolumn{2}{|c|}{$\begin{array}{l}\text { Needing to Learn to } \\
\text { Discourage Violence }\end{array}$} \\
\hline & $\mathrm{b}$ & Wald \\
\hline $\begin{array}{l}\text { Are you interested in news or current event programs on radio } \\
\text { or television? }\end{array}$ & $.149^{* \star *}$ & 24.040 \\
\hline Do you need to learn to find people to trust to manage your money? & $.166^{\star \star \star}$ & 88.569 \\
\hline Do you need to learn to organize your own transport? & $.367^{\star \star *}$ & 202.186 \\
\hline Do you want to learn to organize your own transport? & $.061^{*}$ & 5.736 \\
\hline $\begin{array}{l}\text { Do you have any difficulties with ensuring that your home has } \\
\text { appropriate and regular checks of fire detection and prevention } \\
\text { devices (e.g., smoke alarms, fire extinguisher, fire blanket)? }\end{array}$ & $.278^{*}$ & 4.534 \\
\hline Gender & $.288^{* * *}$ & 26.858 \\
\hline Age & $.009^{*}$ & 5.880 \\
\hline Combined Income & $-.102^{\star \star *}$ & 17.747 \\
\hline
\end{tabular}

${ }^{\star \star *} p<.001,{ }^{* *} p<.01,{ }^{*} p<.05$. 
Other significant factors that predicted the need to learn to discourage violence were as follows:

- being older;

- needing and wanting to learn to organise their own transport; and

- having difficulties ensuring their home had appropriate and regular checks of fire detection and prevention devices.

Results for the ordinal regression model for the second dependent variable, "wanting to learn to discourage violence," are presented in Table 2. As with the previous analysis, only the items that emerged as predictors of wanting to learn to discourage violence are discussed in detail. The respondents who were more likely to say that they wanted to learn to discourage violence against them (Table 2$)\left[\chi^{2}(8, n=2412)=1422.20\right.$, $p<.001]$ were those who were

- interested in news or current event programs on radio or television;

- wanted to learn to find people to trust to manage their money;

- needed and wanted to learn to organise their own transport;

- seldom attended meetings of social clubs, religious meetings or other groups that they belonged to;

- more likely women; older; and in lower combined income brackets.

TABLE 2. Ordinal Regression Analysis with Wanting to Learn to Discourage Violence as the Dependent Variable

\begin{tabular}{|c|c|c|}
\hline \multirow[t]{2}{*}{ Questions } & \multicolumn{2}{|c|}{$\begin{array}{l}\text { Wanting to Learn to } \\
\text { Discourage Violence }\end{array}$} \\
\hline & $\mathrm{b}$ & Wald \\
\hline $\begin{array}{l}\text { Are you interested in news or current event programs } \\
\text { on radio or television? }\end{array}$ & $.154^{\star \star \star}$ & 27.435 \\
\hline Do you need to learn to organize your own transport? & $.071^{\star \star *}$ & 10.211 \\
\hline $\begin{array}{l}\text { Do you want to learn to find people to trust to manage } \\
\text { your money? }\end{array}$ & $.176^{* * *}$ & 102.609 \\
\hline Do you want to learn to organize your own transport? & $.367^{\star \star \star}$ & 214.749 \\
\hline $\begin{array}{l}\text { About how often did you go to meetings of social clubs, } \\
\text { religious meetings or other groups that you belong to } \\
\text { in the past week? }\end{array}$ & $-.080^{\star * *}$ & 21.152 \\
\hline Gender & $.319^{\star \star \star}$ & 35.404 \\
\hline Age & $.018^{* * *}$ & 23.485 \\
\hline Combined Income & $-.107^{\star \star *}$ & 21.751 \\
\hline
\end{tabular}

${ }^{* * *} p<.001,{ }^{* *} p<.01,{ }^{*} p<.05$. 


\section{Open Comments}

Responses of women aged 65 years and over were searched for terms such as news, current events and media, (including radio, television and newspapers), transport (including cars), finances and money; social outings (shopping, church, family), and risk and safety.

In summary, the analysis found that as their age increased, female respondents were more likely than other respondents to say they needed and wanted to learn to protect themselves against violence. The results confirm that older Australian women have concerns about violence, and highlight the issues associated with their need to learn how to protect themselves.

\section{DISCUSSION}

It is well known that older people are less represented in statistics as victims of crime and violence than other groups (Caracach and Mukherjee, 1999; Graycar and James, 2000). For instance, the majority of physical and sexual assaults in official statistics relate to the 15 to 24-year age group (Graycar and James, 2000, p. 3). This study reveals a disturbing trend-as the age of women increased those on lower incomes were more likely than others to indicate that they wanted to learn how to discourage violence against themselves. Among the predictors were other learning requirements: learning how to find people to trust to manage finances and learning how to organise transport. Other predictors were being interested in news or current event programs on radio or television; an inability to maintain safety equipment within the home; and low social participation in social clubs, religious meetings or other groups. Ironically, women on low incomes are often the most dependent on others and least able to engage in programs regarding protection against violence and abuse.

It has been generally agreed that, in spite of being less likely to be victims, the consequences of crime impact older people more than the younger people and increases their levels of fear (Graycar and James, 2000). Currently "the debate about crime and older people is wider and more controversial than it has ever been" (Graycar and James, 2000). The following discussion raises questions about the importance for older women to live free of fear, confident and secure in their homes, and be able to participate fully in the life of their communities. 


\section{Media and Perceptions of Risk}

The finding of an association between the media (news or current events on radio or television) and older women's perceptions of susceptibility to violence is strongly supported by research. Gerbner, Gross, Morgan and Signorielli (1980) suggest that "the more time one spends 'living' in the world of television, the more likely one is to report perceptions of social reality which can be traced to (or are congruent with) television's most persistent representation of life and society" (p. 14). Hence, there is a significant positive association between older people, television viewing, and a belief that older people are most likely to be victims of violence (Gerbner et al., 1980). In a study of the impact of television reports on audience age groupings, the standard version of a prison escape (rather than the reassuring version, or remote location version) evoked the most fearful responses from older people, especially women (Fisher, Allan and Allan, 2004). Sensationalising crimes in the media can heighten a sense of defencelessness for older isolated people (James, 1993), construct "risk" as danger and uncertainty, and magnify "levels of alarm" (Joffe, 1999, p. 2).

In a specific study of America's Most Wanted, a reality television program screened in prime time, Cavender, Bond-Maupin and Jurik (1999) found media depictions highlighted women's vulnerability to attack, and reinforced the culturally dominant views of masculinity and femininity. Historical silence surrounding abuse and violence is embedded in the lives of many older women who may "relive" experiences when viewing media depictions of violence; and even in everyday talk, ideas about women's vulnerability and men's dangerousness are commonplace (Hollander, 2001). Understandably, older women perceive themselves as generally "at-risk" individuals in society, and may indeed be so. Therefore, fear of violence needs to be recognized as a barrier to their social participation and well-being.

\section{Money, Transport, Travel and Women's Needs}

Two predictors of the needs expressed by older women to learn to discourage violence were other learning needs: to learn to find people to trust to manage their money and to learn how to organise their own transport. One of the factors that might be associated with finances is that, as women typically outlive men, many will live alone without the knowledge of money matters previously handled by a spouse (Into, 2003). Women alone may have difficulty finding a trusted confidante 
and research confirms that consumer fraud is most prevalent for older Australians, and a significant contributor to their experiences of crime (Muscat, James and Graycar, 2002). Yet financial abuse is often unrecognised. Older, poorer women are likely to be abused from others living in their homes or from family members (Woolgate, 2000) who may take advantage of a caring relationship to benefit financially. Elder abuse, in its many forms, is a public health priority, yet identification of issues and intervention is highly problematic (Schofield and Mishra, 2004), and incidents of financial abuse are likely to increase as more women live to oldest age (Brandl and Horan, 2002). A small study about money and older women's susceptibility to poverty suggests that early intervention to educate women is essential because "maintaining control of their daily financial matters" will enable them to age successfully (Into, 2003, p. 827).

It is not surprising that transport appears in association with older women and their safety concerns. Widowhood, the loss of car transport and safe mobility (Gilleard and Higgs, 2005) may make women fearful when venturing out in public (Pain, 1997). Owning and driving a car ensures independence and avoids risks, as the following extract encapsulates:

I want to retain the ability to keep my independence, to be mobile and pain free, to keep driving my car capably and to have the energy to do some voluntary work, as well as keep my home more tidy and clean. I would like more social life but am handicapped somewhat because by husband has bad health and spends most of his days resting at home. (78 years)

Independence, mobility and energy are the intrinsic resources identified by this woman, and driving is the essential capacity that ensures continuity of voluntary work and social activities. With mention of a dependent spouse and lack of children, several impending losses may increase her social isolation. Another study of women and fear found respondents frequently mentioned fear of physical attack, and it was "the social nature of these different places which provokes fear, including the reputation of places as dangerous or safe" (Koskela and Pain, 2000). Avoiding situations where they feel unsafe is likely to reduce social activities and movements beyond the home. A study respondent commented that it was important "to be able to feel safe when travelling to and from any activity, being able to travel both within Australia and 
overseas, but the worry in travel overseas is it is too great to really undertake" (64 years).

The Women's Safety Australia study (McLennan, 1996) found that younger women were more likely to feel unsafe in a range of situations, with 40\% aged 18-24 years feeling unsafe on public transport compared with $12 \%$ aged 60 years and over. However, older women were much less likely to use public transport, and $93 \%$ did not use public transport after dark (McLennan, 1996). On the basis of gender, women's fear of crime is "normalised" through the life course, and those on low incomes without private transport are even more exposed to violence and fear (Koskela and Pain 2000). Transport options planned for the future need to recognise women's concerns about safe transport "mobility and accessibility" (Root, 2000).

\section{Home Security and Safety: Environmental and Personal}

Anxiety about personal safety and security might explain the association between fears of violence and an inability to ensure that homes have appropriate and regular checks of fire detection and prevention devices (e.g., smoke alarms, fire extinguisher, fire blanket). If women cannot purchase or maintain protective devices, they may feel at risk of fire emergencies in their homes. Security grilles and doors protect from intruders but also imprison the occupant. Women's relationship to the physical environment (buildings and especially interiors) has traditionally been seen as interdependent; the house moulded by the woman while the woman is expressed or defined by it (Kinchin, 1996; Ockman, 1996). The house has been associated with a sense of identity and the ability to feel "at home" (Marcus, 1997; Ridoutt, Sueyoshi, Ball, Miyazaki, and Morikawa, 2005). The practice of barricading oneself inside the house raises questions about the shift from shelter to barricade or trap (in the case of risk against fire); it presents challenges for the design and modification of houses for those older people who live at home.

Previous experiences of violence are also barriers to women's ability to move freely outside the home. Australian-born $(\mathrm{n}=362)$ women aged between 51 and 62 years responded to a self-administered "violence questionnaire" that asked about sexual abuse in both childhood and adult life (Mazza, Dinnerstein, Garamszegi and Dudley, 2001). Surprisingly, $8.9 \%$ had experienced childhood physical abuse, $28.5 \%$ had experienced some physical or emotional abuse in their lifetime, and overall, $40.8 \%$ had experienced unwanted sexual advances or threats of sexual assault and violence. Canadian women have also reported 
that "they had altered their routines to avoid or manage risky situations" (Scott, 2003). Such findings confirm women's experiences and expectations of violence (Koskela and Pain, 2000).

Clear identification of violence against older women in their homes is confounded by possible long-standing wife abuse and caregiver abuse (Phillips, 2000) making it difficult to determine mistreatment (forms of elder abuse) from domestic violence; and there is little research about gender differences that may highlight the plight of older women (Fulmer, Guadagno, and Bolton, 2004). Australian policy directions are moving towards identification and protection of victims of violence within the home, yet, for older people, the alternatives are likely to cause even more distress than remaining in the abusive situation or relationship (Kinnear and Graycar, 1999).

The Importance of the Neighbourhood for Older Women

Women who reported wanting to protect themselves against violence were those less likely to have gone to meetings of social clubs, religious meetings or other groups that they belonged to, in the past week. Sadly, a study of the connections between mental health, civic participation and perceptions of safety in communities found that feelings about fear, violence and safety were mentioned frequently (Ziersch, Baum, MacDougall and Putland, 2005). Fearfulness of attack raises concerns about the ability to fight off an attacker, and the capacity to recover from physical injury (Johnson, 2005, p. 33). Isolation on the basis of such fears is understandable, but particularly harmful for poorer, older people, for whom neighbours and "neighbouring" are more important than they are for more affluent residents (Forrest and Dearns, 2001). An in-depth study of five older women noted that respondents identified strongly with the interiors of their homes, but also "experienced physical and cognitive 'reach' beyond their homes via social activities, travel, observation and surveillance of the yard and neighborhood, reading, television, daydreams, and fantasies" (Swenson, 1998, p. 389).

When indicated in a large study, fear of violence is a serious barrier that may inhibit the physical "reach" of older women into public environments-their neighbourhoods and communities. A 68-year-old respondent commented, "Active ageing means to be healthy, independent, learning, socialising, supporting and supported, teaching, safe and to be able to do what I want to do, when and how." In addition, extreme fear and self-exclusion from public space has a detrimental impact on 
the character of communities (Johnson citing Skogan, 2005, p. 29), with communities the poorer for the reduced participation of older people. Older women are "more closely connected to their community, unlike their men, who tended to have progressively weaker ties to their community as they grew older" (Gilleard and Higgs, 2005, p. 139). It is concerning to see in the results reported in this paper that protection against violence is as an issue for older women, since $f$ ear of crime that limits relationships and participation in the wider community can, potentially, inhibit well-being (Australian Bureau of Statistics, 2002).

\section{Education and Interventions}

Previous analysis of the Triple A data found that gender was significant for wanting and needing to learn, as well as for needing independence and protection (Boulton-Lewis, Buys and Lovie-Kitchin, 2006). This study adds to knowledge by drawing attention specifically to the needs of older, poorer women who want to learn strategies for protecting themselves against violence. A review of interventions targeting social isolation among older people found, despite shortcomings, there were useful guidelines-"high quality approaches to the selection, training and support of the facilitators or co-ordinators of the interventions"; involvement of "older people in the planning, implementation and evaluation stages"; use of "existing community resources and aim to build community capacity" (Findlay, 2003, p. 655). Group interventions containing aspects of education or training, and social activities that targeted specific groups such as "women, caregivers, the widowed" were promising, (Cattan, White, Bond and Learmonth, 2005); and a feminist organising process to target poorer women and improve their inclusion in community have been successful (Ponic and Frisby, 2005).

\section{CONCLUSION}

Research consistently indicates that older people do not experience excessive levels of crime and violence, yet this study finds a small but significant group-older women on low incomes-do have negative perceptions about their vulnerability. As the age of women increased, they were more likely to say that they needed and wanted to learn how to protect themselves against violence. Older women's fear of violence has both personal and environmental dimensions. They may feel exposed to danger because of their smaller size and lesser strength when they are in 
the public domain or in their homes; because of their limited finances, lack of transport, inability to maintain home protections, or mistrust of others. Women may also have experienced violence across the lifespan. The most detrimental aspects of fears of violence are deficits in health and well-being through social isolation of individuals, and the subsequent loss to communities of the contribution of older citizens.

The media has the capacity to educate and inform about protective measures, although it may negatively impact on older women's perceptions of violence. It is essential in light of the findings reported in this paper to understand older women in the context of their personal and environmental relationships, and to provide information and learning opportunities that improve their confidence, safety and social engagement.

\section{REFERENCES}

Australian Bureau of Statistics. (2002). Population Projections, Australia, 1999 to 2001. Cat. No 3222.0.

Beck, U. (1992). Risk Society: Towards a New Modernity. London, UK: Sage.

Beck, U. (1995a). Ecological Enlightenment: Essays on the Politics of the Risk Society (M. A. Ritter, Trans.). New Jersey: Humanities Press.

Beck, U. (1995b). Ecological Politics in an Age of Risk (A. Weisz, Trans.). Cambridge, UK: Polity.

Blythe, M. A., Wright, P. C., \& Monk, A. F. (2004). Little brother: Could and should wearable computing technologies be applied to reducing older people's fear of crime? Personal Ubiquitous Computing, 8, 402-415.

Boulton-Lewis, G., Buys, L., \& Lovie-Kitchin, J. (2006). Learning and active aging. Educational Gerontology, 32(4), 271-282.

Brandl, B. \& Horan, D. L. (2002). Domestic violence in later life: An overview for health care providers. Women \& Health, 35(2-3), 41-54.

Caracach, C. \& Mukherjee, S. (1999). Women's Fear of Violence in the Community. Canberra, ACT: Australian Institute of Criminology.

Cattan, M., White, M., Bond, J., \& Learmouth, A. (2005). Preventing social isolation and loneliness among older people: A systematic review of health promotion interventions. Aging \& Society, 25, 41-67.

Cavender, G., Bond-Maupin, L., \& Jurik, N. (1999). The construction of gender in reality crime TV. Gender \& Society, 13(5), 643-666.

Findlay, R. A. (2003). Interventions to reduce social isolation amongst older people: Where is the evidence? Aging \& Society, 23, 647-658.

Fisher, S., Allan, A., \& Allan, M. M. (2004). Exploratory study to examine the impact of television reports of prison escapes on fear of crime, operationalised as state anxiety. Australian Journal of Psychology, 56(3), 181-190.

Forrest, R. \& Dearns, A. (2001). Social cohesion, social capital and the neighbourhood. Urban Studies, 38(12), 2125-2143. 
Fulmer, T., Guadagno, L., \& Bolton, M. M. (2004). Elder mistreatment in women. Journal of Obstetrics, Gynaecology and Neonatal Nursing, 33(5), 657-663.

Gerbner, G., Gross, L., Morgan, M., \& Signorielli, N. (1980). The "Mainstreaming” of America: Violence Profile No. 11. Journal of Communication, 30(3), 10-29.

Gilleard, C. \& Higgs, P. (2005). Contexts of Ageing: Class, Cohort and Community. Cambridge, UK: Polity.

Graycar, A. \& James, M. (2000). Crime and older Australians: Understanding and responding to crime and older people. Paper presentedat the Family Futures: Issues in Research and Policy. 7th Australian Institute of Family Studies Conference, Sydney.

Hollander, J. A. (2001). Vulnerability and dangerousness: The construction of gender through conversation about violence. Gender \& Society, 15(1), 83-109.

Into, F. H. (2003). Older women and financial management: Strategies for maintaining independence. Educational Gerontology, 29, 825-839.

James, M., Graycar, A., \& Mayhew, P. (2003). A Safe and Secure Environment for Older Australians. Canberra, ACT: Australian Institute of Criminology.

James, M. P. (1993). Fear reduction. Crime prevention for older Australians. Crime Prevention Series, 44-53.

Joffe, H. (1999). Risk and "the Other." Cambridge: University Press.

Johnson, H. (2005). Crime Victimisation in Australia: Key Results of the 2004 International Crime Victimisation Survey: Australian Institute of Criminology.

Kinchin, J. (1996). Interiors. Nineteenth century essays on the "masculine" and the "feminine" room. In P. Kirkham (Ed.), The Gendered Object (pp. 12-29). Manchester, UK: Manchester University Press.

Kinnear, P. \& Graycar, A. (1999). Abuse of Older People: Crime or Family Dynamics? Canberra, ACT: Australian Institute of Criminology.

Koskela, H. \& Pain, R. (2000). Revisiting fear and place: Women's fear of attack and the built environment. Geoforum, 31, 269-280.

Marcus, C. C. (1997). House as a Mirror of Self: Exploring the Deeper Meaning of Home. Berkeley, CA: Conari Press,.

Mazza, D., Dennerstein, L., Garamszegi, C. V., \& Dudley, E. C. (2001). The physical, sexual and emotional violence history of middle-aged women: a community-based prevalence study. The Medical Journal of Australia, 175(4), 199-201.

McLennan, V. (1996). Women's Safety Australia. Canberra, ACT: Australian Bureau of Statistics.

Muscat, G., James, M., \& Graycar, A. (2002). Older people and consumer fraud. Trends \& Issues in Crime and Criminal Justice, Australian Institute of Criminology (p. 220).

Mythen, G. (2004). Ulrich Beck: A Critical Introduction to the Risk Society. London, UK: Pluto.

Ockman, J. (1996). Mirror images. Technology, consumption, and the representation of gender in American architecture since World War II. In D. E. A. Agrest (Ed.), The Sex OF Architecture (pp. 191-210). New York, NY: Harry N. Abrams.

Olsberg, D., Perry, J., Encel, S., \& Adorjany, L. (2004). Ageing in Place: Intergenerational and Intra-Familial Housing Transfers and Shifts in Later Life. Brisbane: AHURI (Australian Housing Urban Research Institute).

Pain, R. H. (1997). "Old age" and ageism in urban research: The case of fear of crime. International Journal of Urban and Regional Research, 21(1), 117-128. 
Phillips, L. R. ( 2000). Domestic violence and aging women. Geriatric Nursing, 21(4), 188-193.

Ponic, P. \& Frisby, W. (2005). Feminist organizing as community development: A strategy for delivering accessible recreation to women living in poverty. Paper presented at The Two Solitudes: Isolation or Impact? The 11th Canadian Congress on Leisure Research, Department of Recreation and Tourist Management, Malaspina University-College, Nanaimo, B.C.

Purdie, N. \& Boulton-Lewis, G. M. (2003). The learning needs of older adults. Educational Gerontology, 29(2), 129-149.

Ridoutt, B. G., Sueyoshi, S., Ball, R. D., Miyazaki, Y., \& Morikawa, T. (2005). Homeowner identity symbolism in Japanese housing constructions. Forest Products Journal, 55(4), 31-37.

Root, A. (2000). Women, travel and the idea of "sustainable transport." Transport Reviews, 20(3), 369-383.

Schofield, M. J. \& Mishra, G. D. (2004). Three year health outcomes among older women at risk of elder abuse: Women's Health Australia. Quality of Life Research, 13, 1043-1052.

Schroder-Butterfill, E. \& Marianti, R. (2006). A framework for understanding old-age vulnerabilities. Aging \& Society, 26, 9-35.

Scott, H. (2003). Stranger danger: Explaining women's fear of crime. The Western Criminology Review, 4(3).

Swenson, M. M. (1998). The meaning of home to five elderly women. Health Care for Women International, 19(5), 381-393.

Wiles, P. \& Simmons, J. (2003). Crime victimisation: Its extent and communication. Journal of the Royal Statistical Society, 166(2), 247-252.

World Health Organisation (2005). Active Ageing: A Policy Framework. http:// www.who.int/hpr/ageing/ActiveAgeingPolicyFrame.pdf

Woolgate, D. (2000). Aged target of abuse, Illawarra Mercury.

Ziersch, A. M., Baum, F. E., MacDougall, C., \& Putland, C. (2005). Neighbourhood life and social capital: The implications for health. Social Science and Medicine, 60, 71-86.

RECEIVED: 09/22/06
REVISED: $10 / 09 / 06$
ACCEPTED: $10 / 29 / 06$

doi:10.1300/J074v19n03_12 